\title{
GAMBARAN DEBRIS INDEKS PADA IBU HAMIL DI POLIKLINIK KANDUNGAN RSUD KABUPATEN SORONG PROVINSI PAPUA BARAT
}

\author{
Faradila Anakoda ${ }^{1}$, Jeana Lydia Maramis ${ }^{2}$ \\ (1) RSUD Kabupaten Sorong Jl. Sorong Klamono Km 22 Kota Sorong Propinsi Papua Barat \\ (2) Jurusan Kesehatan Gigi Poltekkes Kemenkes ManadoJl.RW Mongisidi Malalayang II Manado
}

Email : jeanalydiamaramis@gmail.com

\begin{abstract}
ABSTRAK
Pendahuluan : Kesehatan ggi dan mulut penting bagi kesehatan dan kesejahteraan tubuh secara umum dan sangat mempengaruhi kualitas kehidupan, termasuk fungsi bicara, pengunyahan dan rasa percaya diri. Mengukur kebersihan gigi dan mulut merupakan upaya untuk menentukan keadaan kebersihan gigi dan mulut seseorang. Debris adalah bahan lunak yang menempel pada permukaan gigi dan juga mengandung bakteri. Untuk mengukur kebersihan gigi menggunakan skor debris indeks. Seseorang yang mengalami kehamilan tidak hanya fisik dan mental yang harus diperhatikan, tapi kebersihan dan kesehatan gigi dan mulut juga harus diperhatikan, karena meskipun tidak tampak dari luar, dampak yang akan ditimbulkan sangat besar bagi kesehatan ibu dan bayi. Penelitian ini bertujuan untuk mengetahui kriteria Debris Indeks pada ibu hamil di Poliklinik Kandungan RSUD Kabupaten Sorong Provinsi Papua Barat. Metode : Penelitian ini menggunakan metode deskriptif, yang dilaksanakan pada bulan Juni 2019. Jumlah populasi dalam penelitian ini sebanyak 32 responden, sampel dalam penelitian diambil total populasi. Untuk mengukur Debris Indeks pada ibu hamil, menggunakan format pemeriksaan Debris Indeks, data yang diperoleh direkapitulasi dan disajikan dalam bentuk tabel distribusi frekuensi. Hasil : Berdasarkan hasil penelitian Debris Indeks pada ibu hamil di Poliklinik Kandungan RSUD Kabupaten Sorong Provinsi Papua Barat, hasil penelitian yang dilakukan pada 32 responden didapat kriteria buruk yang paling banyak, yaitu sebanyak 19 responden $(59,4 \%)$. Kesimpulan : Debris Indeks (DI) ibu hamil trimester pertama dan kedua di Poliklinik Kandungan RSUD Kabupaten Sorong Provinsi Papua Barat terbanyak berada pada kategori buruk.
\end{abstract}

\section{Kata Kunci : Debris Indeks, Ibu Hamil}

\begin{abstract}
Introduction : Dental and oral health are important to the general health and well-being of the body and greatly affect the quality of life, including speech, chewing and self-confidence. Measuring dental and oral hygiene is an attempt to determine the condition of a person's oral and dental hygiene. Debris is a soft material that sticks to the surface of the teeth and also contains bacteria. To measure dental hygiene using a debris index score. A person experiencing pregnancy is not only physically and mentally that must be considered, but hygiene and oral health must also be considered, because even though it is not visible from the outside, the impact will be very large for the health of mother and baby. This study aims to see the Debris Index criteria for pregnant women at the Gynecology Polyclinic of the Sorong District Hospital, West Papua Province. Methods : This study used a descriptive method, which was conducted in June 2019. The total population in this study was 32 respondents, the total population sample in the study was taken. To measure the Debris Index in pregnant women, using the Debris Index examination format, the data obtained is recapitulated and presented in the form of a frequency distribution table. Result : Based on the results of research on the Debris Index for pregnant women at the Gynecology Polyclinic
\end{abstract}


of the Sorong Regency Regional Hospital, West Papua Province, the research conducted on 32 respondents determined the most bad criteria, namely 19 respondents (59.4\%). Conclusion : Debris Index (DI) of pregnant women in the first and second trimesters of the Gynecology Polyclinic at the Sorong District Hospital, West Papua Province, were mostly in

the bad category.

\section{Keywords: Debris Index, Pregnant Women PENDAHULUAN}

Kesehatan merupakan bagian terpenting dalam kehidupan manusia, sehat secara jasmani dan rohani tidak terkecuali anak-anak, setiap orang tua menginginkan anaknya bisa tumbuh dan berkembang secara optimal, hal ini dapat dicapai jika tubuh mereka sehat. Kesehatan yang perlu diperhatikan selain kesehatan tubuh secara umum, juga kesehatan gigi dan mulut. Karena kesehatan gigi dan mulut dapat mempengaruhi kesehatan tubuh secara menyeluruh. Dengan kata lain bahwa kesehatan gigi dan mulut merupakan bagian integral dari kesehatna tubuh secara keseluruhan yang tidak dapat dipisahkan dan kesehatan tubuh secara umum. ${ }^{1}$

Kehamilan merupakan suatu proses fisiologis yang dapat menimbulkan perubahan-perubahan pada tubuh wanita, baik fisik maupun psikis karena pengaruh natural hormones saat kehamilan disertai berbagai keluhan jadi seperti ngidam, mual, muntah termasuk keluhan sakit gigi dan mulut. ${ }^{2}$

Tahap-Tahap Kehamilan, yaitu pertama; Trimester Pertama (0-12 Minggu), tahap ini merupakan masa penyesuaian terhadap kehamilan, pertumbuhan janin masih berlangsung lambat sehingga kebutuhan gizi untuk pertumbuhan janin juga belum begitu besar. Penambahan berat dalam trimester pertama kurang dari satu kilogram. Biasanya pada masa kehamilan pertumbuhan gusi yang mudah berdarah. Hal ini karena jaringan gusi merespon secara berlebihan terhadap iritasi lokal. Tahap kedua yaitu; Trismeter Kedua (1224 Minggu). Pada tahap ini pertumbuhan janin berlangsung cepat, seluruh penambahan berat badan ibu selama masa kehamilan terjadi pada masa ini. Selera makan menjadi normal kembali bahkan kadang-kadang semakin meningkat, kemampuan mencerna pada tahap ini semakin membaik. Pada trimester kedua gusi akan seperti membulat, permukaan licin mengkilat, berwarna merah menyala, konsistensi lunak, mudah berdarah bila kena sentuhan, dan tahap ketiga yaitu Trimester Ketiga (24-40 Minggu). Pada tahap ini pertumbuhan bayi tidak secepat tahap sebelumnya. Pembengkakan yang terjadi pada gusi mencapai puncaknya pada bulan ketujuh dan kedelapan, meskipun setelah melahirkan peradangan gusi tersebut akan hilang dengan sendirinya tetapi tetap akan merupakan sumber peradangan bila kebersihan gigi dan mulut tidak dipelihara dengan baik dan benar. ${ }^{3}$

Debris indeks yaitu skor yang didapat dari endapan lunak karena adanya sisa makanan yang melekat pada permukaan gigi penentu. Untuk melakukan penilaian debris, dapat membagi permukaan gigi yang akan dinilai dengan garis khayal menjadi tiga bagian yang sama besar.

Cara Penilaian debris Indeks, dapat dilihat pada tabel 1 di bawah ini :

Tabel 1. Kriteria Skor Debris

\begin{aligned} & \hline Skor \multicolumn{1}{c}{ Kondisi } \\ & \hline 0 Tidak ada debris atau stain \\ & 1 $\begin{array}{l}\text { Plak menutup tidak lebih dari 1/3 } \\ \text { permukaan servikal, atau terdapat } \\ \text { stain ekstrinsik di permukaan yang } \\ \text { diperiksa }\end{array} \\ & 2 \begin{array}{l}\text { Plak menutup lebih dari 1/3 tapi } \\ \text { kurang dari 2/3 permukaan yang } \\ \text { diperiksa } \\ \text { Plak menutup lebih dari 2/3 } \\ \text { permukaan yang diperiksa }\end{array} \\ &$\hline\end{aligned}


Debris indeks yaitu jumlah seluruh skor segmen dibagi jumlah segmen (6) gigi-gigi yang dipilih sebagai indeks beserta permukaan indeks yang dianggap mewakili tiap segmen, ke 6 gigi indeks tersebut yaitu : Gigi 16 pada permukaan bukal, Gigi 11 pada permukaan labial, Gigi 26 pada permukaan bukal, Gigi 36 pada permukaan lingual, Gigi 31 pada permukaan labial, Gigi 46 pada permukaan lingual.

Jika gigi indeks pada suatu segmen tidak ada, maka lakukan penggantian gigi tersebut dengan ketentuan sebagai berikut : 1. Jika gigi 6 (M1) tiak ada maka penilaian dilakukan pada gigi 7 (M2), bila gigi kedua tidak ada maka penelitian dilakukan pada gigi 8 (M3), akan tetapi jika gigi 6 (M1), 7 (M2), 8 (M3), tidak ada penolaian untuk segmen tersebut.

2. Jika gigi 11 kanan atas tidak ada, dapat diganti oleh gigi 11 atas kiri dan jika gigi 11 kiri bawah tidak ada, dapat diganti oleh gigi 11 kanan bawah, akan tetapi jika gigi 11 kiri dan 11 kanan tidak ada, maka tidak ada penilaian untuk segmen tersebut.

3. Gigi indeks dianggap tidak ada pada keadaan-keadaan seperti gigi hilang karena dicabut gigi yang merupakan sisa akar gigi (Putri dkk, 2013).

Skor indeks debris ditentukan dengan cara menjumlahkan seluruh skor kemudian membaginya dengan jumlah segmen yang diperiksa. Misalkan pada suatu pencatatan indeks debris didapat hasil sebagai berikut

$$
\begin{array}{|c|c|c|}
\hline 2 & 1 & 3 \\
\hline 2 & 2 & 3 \\
\text { Maka skor DI }=\frac{13}{6}=2,17
\end{array}
$$

Menurut Greene dan Vermillion, kriteria penilaian debris, yaitu mengikuti ketentuan sebagai berikut

Baik : Jika nilainya antara $0,0-0,6$

Sedang : Jika nilainya antara $0,7-1,8$

Buruk : Jika nilainya antara $1,9-3,0{ }^{4}$

\section{METODOLOGI}

Jenis penelitian yang digunakan yaitu deskriptif, dimana hanya menggambarkan atau mendeskriptifkan data yang dikumpulkan di lapangan secara nyata. Yang menjadi responden dalam penelitian ini yaitu ibu hamil trimester 1 dan trimester 2 yang berkunjung di Poliklinik Kandungan RSUD Kabupaten Sorong dengan jumlah 32 pasien. Analisa yang digunakan pada penelitian ini dengan cara menghitung persentasi atau dibuat distribusi frekuensi.

\section{HASIL}

1. Distribusi responden berdasarkan umur pada ibu hamil di poliklinik kandungan RSUD Kabupaten Sorong Provinsi Papua Barat dapat dilihat pada Tabel 1 di bawah ini :

Tabel 1. Distribusi Frekuensi Responden Berdasarkan Umur

\begin{tabular}{ccc}
\hline $\begin{array}{c}\text { Kelompok } \\
\text { Umur }\end{array}$ & Jumlah & $\begin{array}{c}\text { Presentase } \\
\%\end{array}$ \\
\hline $15-24$ & 7 & 21,9 \\
$25-34$ & 18 & 56,2 \\
$35-44$ & 7 & 21,9 \\
\hline Total & 32 & 100 \\
\hline
\end{tabular}

Pada Tabel 1 di atas menunjukkan bahwa paling banyak rersponden berumur 25-34 tahun yang berjumlah 18 responden $(56,2 \%)$, diikuti berumur 15 24 tahun sebanyak 7 responden $(21,9 \%)$ dan responden berumur 35-44 tahun berjumlah 7 responden $(21,9 \%)$.

2. Distribusi responden tahap kehamilan dapat di lihat pada Tabel 2 di bawah ini

Tabel 2. Distribusi Frekuensi Responden Berdasarkan Trimester Kehamilan

\begin{tabular}{ccc}
\hline $\begin{array}{c}\text { Trimester } \\
\text { Kehamilan }\end{array}$ & Jumlah & $\begin{array}{c}\text { Presentase } \\
\%\end{array}$ \\
\hline Trimester 1 & 15 & 46,9 \\
Trimester 2 & 17 & 53,1 \\
\hline Total & 32 & 100 \\
\hline
\end{tabular}


Berdasarkan distribusi frekuensi responden menurut trimester kehamilan menunjukkan bahwa responden ibu hamil trimester kedua lebih banyak $(53,1 \%)$ dibandingkan dengan trimester pertama yang hanya $46,9 \%$.

3. Distribusi responden menurut debris indeks pada ibu hamil trimester pertama dan kedua di Poloiklinik Kandungan RSUD Kabupaten Sorong Provinsi Papua Barat dapat dilihat pada Tabel 3 di bawah ini :

Tabel 3. Distribusi Responden

Menurut Debris Indeks Pada Ibu Hamil Trimester Pertama Dan Kedua

\begin{tabular}{ccc}
\hline $\begin{array}{c}\text { Kategori } \\
\text { Debris }\end{array}$ & Jumlah & $\begin{array}{c}\text { Presentase } \\
\%\end{array}$ \\
\hline Baik & 1 & 3,1 \\
Sedang & 12 & 37,5 \\
Buruk & 19 & 59,4 \\
\hline Total & 32 & 100 \\
\hline
\end{tabular}

Berdasarkan Tabel 3 di atas, data Debris Indek (DI) ibu hamil trimester pertama dan kedua di Poliklinik Kandungan RSUD Kabupaten Sorong Provinsi Papua Barat, kategori buruk lebih banyak $(59,4 \%)$ dibandingkan dengan kategori sedang $(37 \%)$ dan kategori baik $(3,1 \%)$.

4. Tabel Silang Kriteria Debris Indeks pada masa kehamilan Trimester I dan Trimester II dapat dilihat pada Tabel 4 di bawah ini :

Tabel 4. Tabel Silang Kriteria Debris Indeks Dengan Masa Kehamilan

\begin{tabular}{|c|c|c|c|c|c|}
\hline \multirow{2}{*}{$\begin{array}{c}\text { Masa } \\
\text { Kehamilan }\end{array}$} & \multicolumn{3}{|c|}{ Jumlah } & \multirow{2}{*}{$\mathrm{n}$} & \multirow{2}{*}{$\%$} \\
\hline & Baik & Sedang & Buruk & & \\
\hline Trimester I & 0 & 6 & 9 & 15 & 46,9 \\
\hline Trimester II & 1 & 6 & 10 & 17 & 53,1 \\
\hline Total & & & & 32 & 100 \\
\hline
\end{tabular}

Pada Tabel 4 di atas, menunjukkan bahwa responden dengan kehamilan trimester II mempunyai DI kriteria buruk sebanyak 10 responden, sedangkan yang paling sedikit ibu dengan kehamilan trimester I dengan kriteria baik, 0 responden.

\section{PEMBAHASAN}

Hasil penelitian yang dilakukan menunjukkan bahwa Debris Indeks (DI) ibu hamil trimester pertama dan kedua di Poliklinik Kandungan RSUD Kabupaten Sorong Provinsi Papua Barat paling banyak berada pada kategori buruk $(59,4 \%)$, hal ini disebabkan karena pada masa kehamilan biasanya terjadi perubahan dalam pemeliharaan kesehatan gigi dan mulut yang biasanya timbul perasaan mual, muntah dan takut ketika menggosok gigi karena timbul perdarahan pada gusi atau terlalu lelah dengan kehamilan sehingga ibu hamil malas atau kurang memperhatikan kebersihan gigi dan mulutnya, karena takut muntah saat menggosok gigi. Keadaan mual ini biasanya ibu hamil mengatasinya dengan menghisap permen atau mengunyah permen terus menerus, sehingga dapat terjadinya akumulasi debris. ${ }^{5}$

Kesehatan gigi merupakan salah satu aspek dari kesehatan secara keseluruhan dimana faktor yang mempengaruhi kualitas kesehatan gigi seseorang tidak terlepas dari aspek fisik yang mempengaruhi kualitas kesehatan gigi dan mulut yang disebabkan oleh keadaan yang terdapat di dalam mulutnya sendiri. Aspek mental yang dapat mempengaruhi kualitas kesehatan gigi dan mulut karena sikap, kepercayaan, dan keyakinan seseorang akan mempengaruhi tingkah laku seseorang. Aspek sosial yang mempengaruhi kualitas kesehatan gigi dan mulut biasanya disebabkan oleh nilai budaya yang berkembang di daerahnya, selain itu di dapat pula disebabkan oleh pengaruh sosial ekonomi, yang kurang keadaan ini juga akan mempengaruhi tingkah laku orang tersebut. ${ }^{6}$

\section{KESIMPULAN}

Berdasarkan hasil penelitian yang telah dilaksanakan pada 32 responden ibu hamil trimester pertama dan kedua yang berkunjung di Poliklinik Kandungan RSUD Kabupaten Sorong Provinsi Papua 
Barat, dapat disimpulkan bahwa Debris Indeks (DI) ibu hamil trimester pertama dan kedua di Poliklinik Kandungan RSUD Kabupaten Sorong Provinsi Papua Barat terbanyak berada pada kategori buruk.

\section{SARAN}

1. Petugas Kesehatan Gigi hendaknya dapat meningkatkan upaya pelayanan kesehatan masyarakat yang berorientasi pada ibu hamil dengan pendekatan promotif, misalnya dengan penyuluhan dan bimbingan mengenai kesehatan gigi dan mulut terutama tentang cara menyikat gigi yang benar, frekuensi menyikat gigi yang tepat, mengatur pola makan yaitu dengan menghindari makanan yang manismanis dan mudah melekat pada permukaan gigi, dan sebaiknya makanlah makanan yang mempunyai daya self cleansing yaitu selain mempunyai vitamin $\mathrm{C}$ juga dapat membersihkan gigi seperti makanan, buah-buahan yang berserat dan mengandung air.

2. Disarankan kepada responden agar dapat menjaga kebersihan gigi dan mulut pada masa kehamilan dan memeriksa gigi dan mulut ke dokter gigi 6 bulan sekali.

3. Perlu adanya kerja sama lintas program antara petugas kesehatan gigi dengan petugas Poliklinik kandungan dalam penyuluhan pada ibu hamil tentang cara menjaga dan memelihara kebersihan gigi dan mulut pada masa kehamilan.

\section{DAFTAR PUSTAKA}

1. Soebroto, (2009), Apa yang tidak Dikatakan Dokter Tentang Kesehatan Gigi Anda. Andi Press. Jogjakarta.

2. Hermawan R, 2010, Menyehatkan Daerah Mulut, Buku Biru : Yogyakarta.

3. Depkes RI, 1995 B, Pedoman Pelayanan Kesehatan Gigi dan Mulut Ibu Hami, Ibu Menyusui, Balita dan Anak Prasekolah Secara Terpadudi Rumah Sakit Umum dan Puskesmas, Jakarta

4. Putri, H.M., Herijuliati, L., dan Nurjanah, N., 2013. Ilmu Pencegahan Jaringan Keras Gigi dan Jaringan Pendukung Gigi. PT Buku Kedokteran EGC, Jakarta.

5. Ginanjar, A.M., 2004, "Pedoman Gigi dan Mulut Ibu Hamil." Dian Rakyat. Jakarta

6. Herijuliati. E, 2001, Pendidikan Kesehatan Gigi, Penerbit Buku Kedokteran. 